\title{
The Effect of Nano Zinc Dietary Supplementation on Growth Performance of KUB Chickens
}

\author{
N H D Larasati ${ }^{1}$, B Ariyadi ${ }^{2}$ and N D Dono ${ }^{3 *}$ \\ ${ }^{1}$ Postgraduate student of Animal Science, Faculty of Animal Science, Universitas Gadjah Mada \\ ${ }^{2}$ Department of Animal Production, Faculty of Animal Science, Universitas Gadjah Mada \\ ${ }^{3}$ Department of Animal Nutrition and Feed Science, Faculty of Animal Science, Universitas Gadjah Mada \\ *Corresponding author. Email: nanungdd@ugm.ac.id
}

\begin{abstract}
Current trial was intended to study the effects of nano zinc dietary supplementation on the growth performance of KUB Chickens. Two hundred KUB chicks were distributed randomly into five treatment levels with four replications, and ten chicks in each replicate pen. The dietary nano zinc treatments were: basal diet without nano zinc supplementation (NZ-0) and a basal diet supplementation with nanoparticle zinc oxide at concentrations of 15 ppm (NZ-1), 30 ppm (NZ2), 45 ppm (NZ-3), or 60 ppm (NZ-4). The observed variables were body weight gain, feed intake, and feed conversion ratio (FCR), based on the 10 weeks rearing period. The pooled data were analyzed statistically with one way ANOVA and followed subsequently with Duncan's test for the data with significant difference. Results indicated that dietary supplementation of $60 \mathrm{ppm}$ nano zinc increased body weight gain $(\mathrm{P}<0.01)$ and feed intake $(\mathrm{P}<0.05)$, and reduced FCR $(\mathrm{P}<0.05)$. Taken together, our data indicated that the growth performance of the KUB chickens improved when the diet were supplemented with 60 ppm nanoparticle zinc
\end{abstract}

Keywords: Growth performance, KUB chickens, Nanoparticles, Zinc supplementations.

\section{INTRODUCTION}

Native chicken meat has a good brand in the Asian market because the native chicken meat has a specific texture, taste that is preferred by most Asian people. In Indonesia, the increase in demand of local chicken meat has stimulated the finding of new developed native poultry breeds, such as KUB Chicken. KUB stands from Kampung Unggul Balitbangtan, is a developed native chicken as the result of a rally of studies by the Research Centre for Agriculture, Ministry of Agriculture. In order to have an optimum performance of KUB Chickens as an expression of genetically improved breed, the appropriate supports are needed such as fulfil nutrient requirements, including trace minerals.

Zinc $(\mathrm{Zn})$ is one of the trace elements that essential for growth, appetizer, enzymes component and functions, body and skeletal maintenance, and body immunesystem [1]. In the upper gastrointestinal tract, zinc tend to separate due to the environmental acidic conditions. These separated elements can cooperate with other compounds in the digesta including phytate, fiber, and chelating agents, making them inaccessible for absorption throughout the small intestine. Consequently, zinc supplementation are essential parts of poultry feed and have been commonly added in inorganic structure, such as zinc oxide $(\mathrm{ZnO})$. In poultry feed industry, zinc is recommended to be supplemented 20 to 30 times higher than the common requirement, as the use of inorganic zinc is quite low [2].

Moreover, dietary supplementation of zinc in high amount might influence the uquilibrium of other micro minerals in the body of animal. Long-term addition of zinc has not also been recommended due to the potency of zinc residue deposition in the animal product [3]. Dietary study has to be done to predict the proper dose; as excessive use of elements can disturb animal health and overall performance. One alternative that can be taken is the application of inorganic trace elements in nano size [4]. It has been calculated that application the use of trace elements in nano size are effective Changing inorganic minerals conventional form with nano mineral form is one of dietary strategies that might be used to diminish over supplementation of trace minerals. Lately, minerals in nanoparticles form are successfully used to fulfill the need of minerals in poultry diets. Therefore, the current experiment evaluated the probable effect of 
dietary nano zinc supplementation on the growth performance of KUB chiken.

\section{MATERIAL AND METHODS}

\subsection{Materials}

This study was conducted at the Department of Animal Nutrition and Feed Science, Faculty of Animal Science, Universitas Gadjah Mada. Materials used in this study were KUB chicks, feed ingredients, nano zinc (NZ; Zinc oxide with a size of $50 \mathrm{~nm}$ ), vaccines, and a set of chemicals for proximate analysis. The chemical composition and feed stuff of the diet are expressed in Table 1.

Table 1. The chemical composition and feed stuff of the diets

\begin{tabular}{|c|c|}
\hline Feed ingredients & Composition (\%) \\
\hline Yellow corn & 45.49 \\
\hline Rice bran & 19.00 \\
\hline Soybean meal & 13.50 \\
\hline Meat bone meal & 15.00 \\
\hline Crude Palm Oil & 6.00 \\
\hline L-Lysine $\mathrm{HCl}$ & 0.10 \\
\hline DL-Methionine & 0.11 \\
\hline Vitamin-mineral premix & 0.25 \\
\hline Limestone & 0.05 \\
\hline Salt & 0.50 \\
\hline Total & 100 \\
\hline Chemical composition & Content \\
\hline Crude protein, $\% *$ & 18.03 \\
\hline Crude fiber, \%* & 6.82 \\
\hline Ether extract, \%* & 7.58 \\
\hline Calcium, \%** & 1.86 \\
\hline Total phosphorus, $\%^{* *}$ & 2.06 \\
\hline Zinc, mg/kg** & 53.74 \\
\hline Metabolizable energy, kcal/kg & 3214 \\
\hline
\end{tabular}

\subsection{Methods}

Two hundred one day old KUB chicks were weighed and randomly assigned to five groups with four replicates, and 10 birds in each replicate pen. The KUB chickens were raised in the litter system according to the standard management practices based on Indonesian Agency for Agricultural Research and Development manual books. Drinking water and feed were provided to the chicken by ad libitum. Current experiment was set out in One-way arrangement with completely randomized fashion, using five treatments of dietary nano zinc supplementations. The treatments were: $\mathrm{NZ}-0=$ basal feed without nano zinc supplementation (control); NZ$15=$ basal feed $+15 \mathrm{mg} / \mathrm{kg}$ nano zinc; NZ-30= basal feed $+30 \mathrm{mg} / \mathrm{kg}$ nano zinc; NZ-45= basal feed $+45 \mathrm{mg} / \mathrm{kg}$ nano zinc; NZ-60 $=$ basal feed $+60 \mathrm{mg} / \mathrm{kg}$ nano zinc. The chicken were weekly weighed from DOC until 10 weeks of age. Feed consumption and feed conversion ratio (FCR) were estimated weekly. The data obtained were analyzed using SPSS statistical software (Statistical Product for Service Solution version 22). All collected data which shown significant differences were further analyzes with Duncan's New Multiple Range Test.

\section{RESULT AND DISCUSSION}

\subsection{Feed Intake}

Feed intake, ratio of the 10 weeks KUB Chickens fed diets supplemented with nano zinc were showed in Table 2. During 10 weeks period of study, results showed that nano zinc dietary supplementation at $60 \mathrm{mg} / \mathrm{kg}$ increased feed intake $(\mathrm{P}<0.05)$ by $5.38 \%$ of KUB chicken. The increased feed intake might be due to an increase in the zinc content in the feed and higher intake of nano zinc in the small intestine which is useful in stimulating an increase in appetite. Previous study by [5] showed that feed intake of broiler chicken was increased with the increased levels of dietary zinc in the diets. Zinc is a component of several enzymes, so zinc deficiency can cause low activity of several enzymes so it would decrease the appetite. Nano zinc through gastrointestinal tract membrane rapidly and occurred to reach the cells on the wall of small intestinal lining. The feed intake of broiler chicken was increase with nano zinc supplementation at $90 \mathrm{mg} / \mathrm{kg}$ in feed [6].

\subsection{Body Weight Gain}

Body weight gain of the 10 weeks KUB Chickens fed diets supplemented with nano zinc were showed in Table 2. Nano zinc dietary supplementation at the level of $60 \mathrm{mg} / \mathrm{kg}$ in KUB chicken increased KUB chicken body weight gain $(\mathrm{P}<0.01)$ with an increase of $7.68 \%$. The increasing body weight of KUB chicken with nano zinc dietary supplementation might be associated with the higher feed intake, supplementing more nutrients for daily need of nutrients. Zinc in the diets facilitate better breakdown of proteins, lipids, carbohydrates, and nucleic acids into components readily for absorption in the intestine, through stimulation of enzymes activities in the gut of animals [7]. Higher bioavailability of nano zinc could have fulfilled the amount of zinc which required for body weight development. These results were in harmony with previous researcher, nano zinc dietary supplementation resulted higher body weight gain [8].

\subsection{Feed Conversion Ratio}

Feed convertion ratio of the 10 weeks KUB Chickens fed diets supplemented with nano zinc were showed in 
Table 2. The 10 weeks KUB Chickens growth performance fed diets supplemented with nano zinc

\begin{tabular}{|c|c|c|c|}
\hline Treatments & Feed Intake (g/bird) & Body weight gain (g) & Feed Conversion Ratio \\
\hline$N Z-0$ & $2937.38+35.80^{b}$ & $823.70+10.18^{d}$ & $3.62+0.09^{b}$ \\
\hline$N Z-15$ & $2985.03+58.86^{\mathrm{ab}}$ & $828.22+8.25^{d}$ & $3.61+0.04^{b}$ \\
\hline$N Z-30$ & $3017.90+52.56^{a b}$ & $846.55+6.95^{c}$ & $3.56+0.04^{a b}$ \\
\hline$N Z-45$ & $3045.30+98.37^{a b}$ & $868.44+9.12^{b}$ & $3.52+0.06^{a b}$ \\
\hline$N Z-60$ & $3095.70+74.81^{a}$ & $887.02+8.72^{a}$ & $3.48+0.06^{\mathrm{a}}$ \\
\hline
\end{tabular}

Table 2. Results of the statistical analysis showed that 60 $\mathrm{mg} / \mathrm{kg}$ nano zinc dietary supplementation reduced $(\mathrm{P}<0.05)$ the birds feed conversion ratio $(\mathrm{FCR})$ with 0.14 points reduction. The lower FCR in the group with 60 $\mathrm{mg} / \mathrm{kg}$ nano zinc supplementation might be attributed to the higher feed intake, faster macro-nutrient digestion, and better conversion process of the feed components, which resulted in the higher body weight gain.

FCR describes efficiency in altering digested feed nutrients into body weight gain throughout a particular timeframe. Zinc has been reported as an important part of several digestive enzymes and are recognized in all six enzymes types which include oxidoreductase, transferase, hydrolase, lyase, isomerase, and ligase [9]. Therefore, supplementation of nano zinc might increase the digestion of ingested feed nutrients. The present data are in line with other researcher that $60 \mathrm{mg} / \mathrm{kg}$ nano zinc supplementation improved feed conversion of Giriraja native chickens [10].

\section{CONCLUSIONS}

The obtained data indicated that growth performance of KUB chickens improved when the diet was supplemented with $60 \mathrm{mg} / \mathrm{kg}$ nano zinc.

\section{AUTHORS' CONTRIBUTIONS}

All authors considered and organized the experiments. NHDL carried out the experiments. All authors added and understanding of the important outcomes and also provided helpful suggestions, driven the successful of the study, statistical analysis, and writing the manuscript.

\section{ACKNOWLEDGMENTS}

The authors acknowledge the financial support from the Ministry of Finance, Republic of Indonesia through LPDP Research Grant and on-site research facilities from the Faculty of Animal Science Universitas Gadjah Mada.

\section{REFERENCES}

[1] P.W. Lai, J.B. Liang, L.C. Hsia, T.C. Loh, Y.W. Ho, Effects of varying dietary zinc levels and environmental temperatures on the growth performance, feathering score and feather mineral concentrations of broiler chicks, Asian-Australasian Journal of Animal Scence, vol. 23, 2010, pp. 937945. DOI: https://doi.org/10.5713/ajas.2010.90495

[2] K. Bratz, G. Golz, C. Riedel, P. Janezyk, K. Nockler, T. Alter, Inhibitory effect of high-dosage zinc oxide dietary supplementation on Campylobacter coli excretion in weaned piglets, Journal of Applied Microbiology, vol. 115, 2013, pp. 1194-1202. DOI: $10.1111 /$ jam.12307

[3] C.Y. Zhao, S.X. Tan, S.X. Qiu, J.Q. Pan, Z.X. Tang, Effect dietary zinc oxide nanoparticle on growth performance and antioxidative status in broilers, Biological Trace Element Research, vol. 160, 2014, pp. 361-367. DOI: https://doi.org/10.1007/s12011014-0052-2

[4] P.R. Ferket, E.V. Heugten, T.A.T.G Van Kempen, R. Angel, Nutritional strategies to reduce environmental emissions from non-ruminants, Journal of Animal Science, vol. 80, 2002, pp. 168-182. DOI: https://doi.org/10.2527/animalsci2002.80ESuppl_2E168x

[5] T. Ao, J.L. Pierce, A.J. Pescatore, A.H. Cantor, K.A. Dawson, M.J. Ford, B.L. Shafer, Effects of organic zinc and phytase supplementation in a maize-soybean meal diet on the performance and tissue zinc content of broiler chicks, British Poultry Science, vol. 48, 2007, pp. $690 \quad-\quad 695 . \quad$ DOI: https://doi.org/10.1080/00071660701694072

[6] F. Ahmadi, Y. Ebrahimnezjad, J.G. Ghalehkandi, N.M. Sis, The effect of dietary zinc oxide nanoparticles on the antioxidant state and serum enzymes activity in broiler chickens during starter stage, International Conference on Biological, Civil and Environmental Engineering, Dubai, 2014, pp. 26-28.

DOI: https://dx.doi.org/10.15242/IICBE.C0314120

[7] Z.H. Liu, L. Lu, S.F. Li, L.Y. Zhang, L. Xi, K.Y. Zhang, X.G. Luo, Effects of supplemental zinc source and level on growth performance, carcass traits, and meat quality of broilers, Poultry Science, vol. 90, 2011, pp. 1782-1790. DOI: https://doi.org/10.3382/ps.2010-01215

[8] D. Ibrahim, H.A. Ali, and S.A.M. El-Mandrawy, Effects of different zinc sources on performance, bio distribution of minerals and expression of genes related to metabolism of broiler chickens, Zagazig Veterinary Journal, vol. 45, 2017, pp. 292-304. DOI: 10.21608/ZVJZ.2017.7954 
[9] S.Y. Park, S.G. Birkhod, L.F. Kubena, D.J. Nisbet, S.C. Ricke, Review the role of dietary zinc in poultry nutrition, immunity, and reproduction, Biological Trace Element Research, vol. 101, 2004, pp. 147-163. DOI: https://doi.org/10.1385/BTER:101:2:147

[10]F. Ahmadi, Y. Ebrahimnezhad, N.M. Sis, J.G. Ghalehkandi, The effect of zinc oxide nanoparticle on performance, digestive organs and serum lipid concentration in broiler chicken during starting period, International Journal of Biosciences, vol. 3, 2013, pp. 23-29. DOI: http://dx.doi.org/10.12692/ijb/3.7.23-29 